日作紀（Jpn. J. Crop Sci.） 75 (1) : 28-37（2006）

\title{
長期無施肥栽培桑園の土㖶全窒素含量 および全炭素含量と収量の推移
}

\author{
葉田光雄・白岩立彦・堀江武 \\ (京都大学大学院農学研究科)
}

\begin{abstract}
要旨：1985 年から無施肥裁培（以下，無施肥区）と化学肥料連用裁培（以下，施肥区）を長期間継続する桑園の土畩 全窒素含量および全炭素含量と収量の推移を 2003 年までの 19 年間にわたって比較した。施肥区へは, 年間 $10 \mathrm{a}$ 当り $\mathrm{N}$, $\mathrm{P} ， \mathrm{~K}$ をそれぞれ $30 \mathrm{~kg} ， 20 \mathrm{~kg} ， 20 \mathrm{~kg}$ を春と夏に半量ずつ表面施肥し，無施肥区へは何も施さず，雑草や落葉も圃場 外へ除いた。調査園では, 1985 1990 年までの期間は在来の桑（品種:改良鼠返）が, 1991 年以降は改植した桑（品種： 一ノ瀬）が裁培された。収穫法は, 春虫期は条桑収穫, 晚秋虫期は頂部 4 ～葉を残し下部を摘葉収穫とした。その結果, 無施肥で裁培を長期間継続した戒場において，土壤全窒素含量と全炭素含量がおおむね平衡に保たれ，年間の桑生葉 収量も 1800 ～ $2000 \mathrm{~g} \mathrm{~m}^{-2}$ と安定していることが認められた。植物体によって収奪された窒素量と土壤全窒素含量の収 支から, 平衡に達した無施肥裁培では年間 $17.5 \mathrm{~g} \mathrm{~m}^{-2}$ の窒素の天然供給が推定された。この窒素のソースは不明であ ったが，土壤全窒素含量および全炭素含量の変動から，それらとして下層土から上層の根圈への養分移動，圃場周囲 からの養分流入ならびに土壤中の微生物による大気からの窒素固定とが可能性として考元れた. 桑葉収穫後, 次の 収穫までの期間が長く，かつ当年の施肥効果が現れるのが遅い春虫期収量では無施肥区が，また収穫までの期間が短 く当年の施肥への依存度が高い晚秋虫期収量では施肥区が，それぞれ多収を示した，吸収した養分の分配も，施肥・ 無施肥処理区間に差が認められ，養分の少ない無施肥区では葉身部への窒素の配分割合が施肥区よりも高く，このこ とも無施肥裁培の高い収量の一因と考えられた。
\end{abstract}

キーワード : クワ, 生葉収量, 長期無施肥裁培, 土壤全炭素含量, 土壤全窒素含量, 年次変動.

近代農業は肥料・農薬などの化学物質や外部エネルギー の投入により，作物生産性の向上や生産の効率化をなしと げてきた。桑栽培においても，戦後の高度経済成長政策の 影響もあり，これまで多施肥多収を至上とする技術が主流 を占めてきた。しかし，それら化学物質や外部エネルギー の過度の投入が環境や人間生活に影響を与えることが指摘 されるようになり，近年，人間の健康や環境に重点を扔い た農法に関心が向けられてきている。このような現状から, 桑園における無施肥を含む異なる施肥管理の継続が, 土壤 の養分動態や桑の生育・収量の長期動態におよぼす影響を 総合的に明らかにすることは, 環境調和性の高い桑栽培技 術のための基礎的知見を与える.

水田に扔いては，15 年以上にわたる長期無施肥栽培の 土畩掞よび水稲の生育と収量への影響を長谷川ら（1977）, 川村・中島（1979）, 奥村（1988）などが詳細に報告し, 45 年以上無施肥栽培を継続している水田で, 収量が経年 的に微増することも報告されている（奥村・竹内， 1999, Okumura, 2002)。しかしながら，永年生の桑を長期無施肥 栽培した圃場に関する知見は極めて乏しい。これまで, 肥 培管理の相違が桑園土壤の肥沃度や桑収量に及ぼす影響に ついては, 小澤・田村 (1940), 高岸ら (1985), 稲松ら (1991), 山田ら (1992), 上村ら（1997）など多数の研究 があるが，それらはおおむね短期間の調査に基づくもので あって, 無施肥栽培は桑葉収量を激減させ, 経済育虫に適 さないというものであった。荒川沖積土における有機質お
よび無機質肥料の連用試験の対照区として 13 年間無施肥 栽培を行なった研究では, 無施肥区は無機質肥料連用区に 対し, 5 年目および 13 年目の収量がそれぞれ $50 \%$ および $35 \%$ に減少し (小澤・田村, 1940), 13 年経過後の土壤全 窒素含量および全炭素含量が 0 〜 $10 \mathrm{~cm}$ までの土層で $50 \%$ 程度減少するものの, $110 \mathrm{~cm}$ までの層を平均すると両区に 差異はなかった (小澤・田村, 1941). 火山灰土壤につい ては 5 年間の無施肥を含む肥料試験（高岸ら，1985）があ るものの, これらょりさらに長期にわたって無施肥栽培を 行なった報告は見られない.

特に蟇の飼料となる桑では, 施肥法は収量性のみならず, 桑葉の虫に対する嘫好性や健康性におよぼす影響をも含め て検討することが求められる. 本研究は, いっさいの有機・ 無機物の投入を行わない無施肥裁培の長期継続が, 桑園土 畩の養分供給力と, 桑の生育・収量およびそこで生産され た桑葉の虫の嗜好性と健康性に及ぼす影響を, 化学肥料連 用裁培のそれらと対比して, 全体として明らかにしょうと して行なっているものである。これまでに無施肥栽培で育 てた桑葉が，施肥栽培によるそれよりも虫の喍好性を高め (葉田・堀江, 2002), 病気誘発物質に対する感受性を低下 させる（葉田・堀江，2004）ことを示した. 本報告では, 19 年にわたって継続した無施肥栽培および化学肥料連用 裁培桑園における桑葉収量と土壤全窒素含量抢よび全炭素 含量の長期動態について報告したい. 


\section{材料と方法}

\section{1. 試験圃場と栽培方法}

試験围場（第 1 図）は，長野県松本市中山にあり，東か ら西に向けて平均 $6.8^{\circ}$ の傾斜のある $4.3 \mathrm{a}$ の桑園で, 上 部にニセアカシア林が隣接する。土壤は火山灰土で酸性で ある。試験開始までこの戋場では，1955 年頃植付けた桑樹 （品種：改良鼠返）が慣行栽培されており，毎年 $10 \mathrm{a}$ あた り $\mathrm{N}, \mathrm{P}, \mathrm{K}$ それぞれ $26 \mathrm{~kg}, 10.5 \mathrm{~kg}, 10.5 \mathrm{~kg}$ が化成肥 料で春と夏に分施され，堆肥 (牛糞および半乾燥稲わら) $1500 \mathrm{~kg}$ および苦土石灰 $60 \mathrm{~kg}$ が冬に施されていた。試験開 始にあたって 1984 年に 1 年間全面無施肥栽培し，固場内 の桑の生育に違いがないことを確かめたのち，1985 年 4 月 に圑場中央部の畧方向に対して平行にスチロール板を深さ $50 \mathrm{~cm}$ まで埋めこみ, 傾斜の上部 $2.1 \mathrm{a}$ を無施肥無農薬栽 培区（以下無施肥区と呼ぶ），下部 $2.2 \mathrm{a}$ を化学肥料によ る施肥栽培区（以下施肥区と呼ぶ）とし，春・晚秋虫兼用 桑園として比較栽培試験を開始した。1991 年に，供試した 桑の樹齢が約 35 年と古くなったので，桑（品種：一ノ瀬） を改植したが，畧間 $120 \mathrm{~cm} ，$ 株間 $80 \mathrm{~cm}$ の栽植間隔は改植 前後で同じとした。収穫法は，春掻期（5～6月）は条桑 収穫，晚秋虫期（8９月）は頂部 $4 \sim 5$ 葉を残した下部 の摘葉収穫であった。

施肥区への施肥量は，年間 $10 \mathrm{a}$ 当り $\mathrm{N}, \mathrm{P}, \mathrm{K}$ をそれぞ 孔 $30 \mathrm{~kg}, 20 \mathrm{~kg}, 20 \mathrm{~kg}$ とし, 春（4月下旬）と夏（7月中旬） に半量ずつ表面施肥した後，攪拌により土壤への混入を 行った。無施肥区へは，何も施さないが施肥区への施肥と

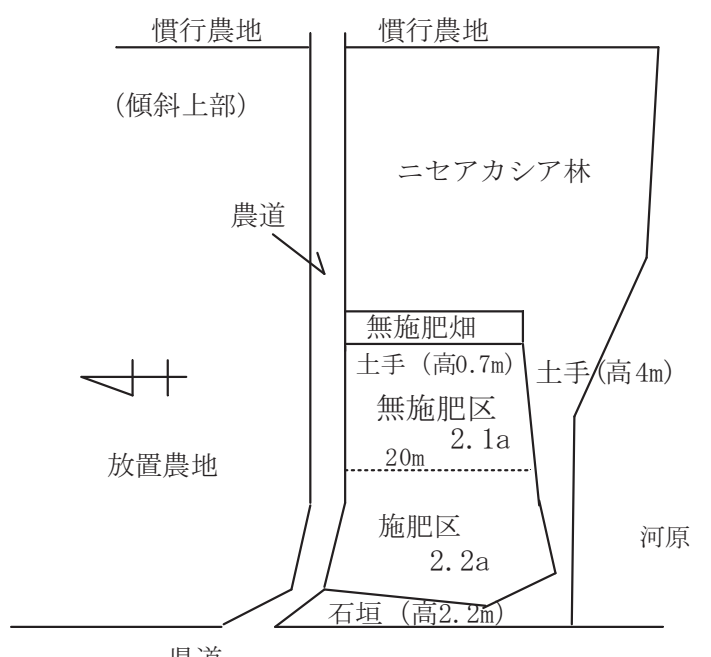

県道

第 1 図 試験围場付近略図.

糐場は東から西に平均 $6.8^{\circ}$ の傾斜地にある。北は 幅 $2.5 \mathrm{~m}$ の農道に面し，東は高さ $70 \mathrm{~cm}$ の土手の上 方に幅 $5 \mathrm{~m}$ の無施肥畑があり，それに隣接して二セ アカシアが自生している．南は高さ $4 \mathrm{~m}$ の土手で傾 斜下方にニセアカシアが自生し，西は高さ $2.2 \mathrm{~m}$ の 石垣で下に県道がある。
同時に，土畩表面の攪汼のみ行った。なお，両区とも年に $3 \sim 5$ 回除草し, また落葉も國場外へ除いた。処理開始後 15 年を経過した 2000 年 7 月には，無施肥区の土壤が $\mathrm{pH}$ $5.80 \pm 0.15$ であったのに対し，施肥区では $\mathrm{pH} 3.84 \pm$ 0.08 の強酸性を示してきたので，2000 年 11 月に施肥区に のみ消石灰を $10 \mathrm{a}$ あたり $65 \mathrm{~kg}$ 全面散布して酸度矯正を行 なった結果， 2001 年 10 月には施肥区の土壌 $\mathrm{pH}$ は $4.78 \pm$ 0.20 になった。

\section{2. 土壤試料の採取および分析法}

1985 年から 2003 年にかけて土壤全窒素含量と全炭素含 量の長期変化の測定を行った。なお 1987 年および 1993〜 1999 年はこれらの測定を欠いた。降雨などの環境の影響が 少ないといわれる（野木，1996）嘼間中央部の土壤のうち, 施肥管理の差が最も顕著に表れる $0 \sim 10 \mathrm{~cm}$ の深さの土䁃 を採取して行った。さらに 2000〜2003 年には畧間中央部 の $0 \sim 10, \quad 10 \sim 30, \quad 30 \sim 50 \mathrm{~cm}$ の各層の土袞の全窒素含量 と全炭素含量を測定し，それらの垂直分布を調べた。土袞 試料は，晚秋蟇期終了後（9月末～10月初）に，各区 3 か 所から採土器を用いて採取し, 風乾した後, 常法（土壤環 境分析法編集委員会，1997）に従い全窒素含量および全炭 素含量は乾式燃焼法, $\mathrm{pH}$ はガラス電極法を用いて分析し た.

\section{3. 収量調査}

収量調査は，春虫期および晚秋蟇期のいずれも奄の 5 齢 盛食期に, 各区の標準的な 3 株について, 収葉重, 条数お よび総条長を計測し，3 個体の平均值を求めるとともに個 体間の変異を統計解析した。 また春虫期には古条重および 新梢重も計測した。重量測定は全て新鮮重と乾物重 $\left(80^{\circ} \mathrm{C}\right.$ 48 時間通風乾燥）について行った。なお 1994 年はこれら の測定を欠いた

桑葉収量は, 栽植密度・条数・条長・葉数・単葉重の要 素にわけることができるが，本試験では栽植密度を等しく しているので, 条長 (平均および単位面積当りの総量) お よび単位条長当りの葉重とに分けて比較した。

\section{4. 植物体の元素含有率の分析}

桑葉，古条抢よび新梢の $\mathrm{N} ， \mathrm{P}, \mathrm{K}, \mathrm{Ca}, \mathrm{Mg}$ の含有率を 以下のようにして調査した。桑葉は，春抢よび晚秋虫期の 収量調査時にそれぞれの株から上位葉と中位葉に分けて採 取したものを乾燥・粉砕した後, 分析に供した。古条およ び新梢は，春虫期の収量調査時に株元から伐採収穫し，乾 燥・粉砕した後, 分析に供した. 粉砕した植物体を硫酸一 過酸化水素分解（水野・南, 1980）したのち, N はインドフェ ノール法， $\mathrm{P}$ は硫酸モリブデン酸法， $\mathrm{K}$ は炎光法， $\mathrm{Ca}$ およ び $\mathrm{Mg}$ は原子吸光法を用いて定量した。 


\section{結 果}

\section{1. 土壤 $\mathrm{pH}$, 土壌全窒素含量および全炭素含量の経年変} 化

晚秋虫期における畧間の土壌 $\mathrm{pH}$ （深さ $0 \sim 10 \mathrm{~cm}$ ）の年 次変動を第 2 図に示した。無施肥区では試験期間を通して pH 5.2〜 5.9 とほとんど変らず推移した。 一方，施肥区で は化学肥料連用 4 年目（1988 年）には $\mathrm{pH} 5$ 以下になり, 1992 年に $\mathrm{pH} 3.8$ に達し, 2000 年も $\mathrm{pH} 3.9$ とほぼ同じ值 となった。 2000 年晚秋虫期後に施肥区のみ酸性矯正をした 結果，2001 年晚秋虫期の施肥区は $\mathrm{pH} 4.8$ となった.

土畩（0１0 cm）の全窒素含量（第 $3 \mathrm{~A}$ 図）は，施肥・ 無施肥区間にほとんど差異は認められなかった。試験開始 1 年目（1985 年）には両処理区とも0.5\%を超えていたが, 処理開始後 2 年から 6 年目ごろまで漸減し, 桑を改植した
処理開始後 6 年目には施肥区で $0.33 \%$, 無施肥区で $0.31 \%$ となった. 処理開始後 16〜19 年（2000～2003 年）に全窒 素含量は無施肥区では $0.43 \%$, 施肥区で $0.40 \%$ の值に達 した。処理全期間の土壤全窒素含量は施肥区が $0.37 \pm$ $0.02 \%$ ，無施肥区が $0.36 \pm 0.02 \%$ であった。

土壤 $(0 \sim 10 \mathrm{~cm})$ の全炭素含量（第 3B 図）は，常に無 施肥区が施肥区を上回る変化を示した。施肥区の全炭素含 量は 1985 年の $4.94 \%$ から 1991 年の $3.21 \%$ まで漸減した。 施肥区の全炭素含量は，2000～2003 年には 3.87\%にとど まっており，1992 年以降その増加は小さいと推察され た. 一方, 無施肥区の全炭素含量は試験開始後 4 年間 (1988 年まで）は $5.69 \%$ でほぼ変化しなかったが，1989年の 5.36\%から 1991 年の3.81\%にかけて減少した。無施肥区 の全炭素含量は 2000～2003 年には 4.84\%に回復しており， 1992 年以降それが漸増したものと推察された。

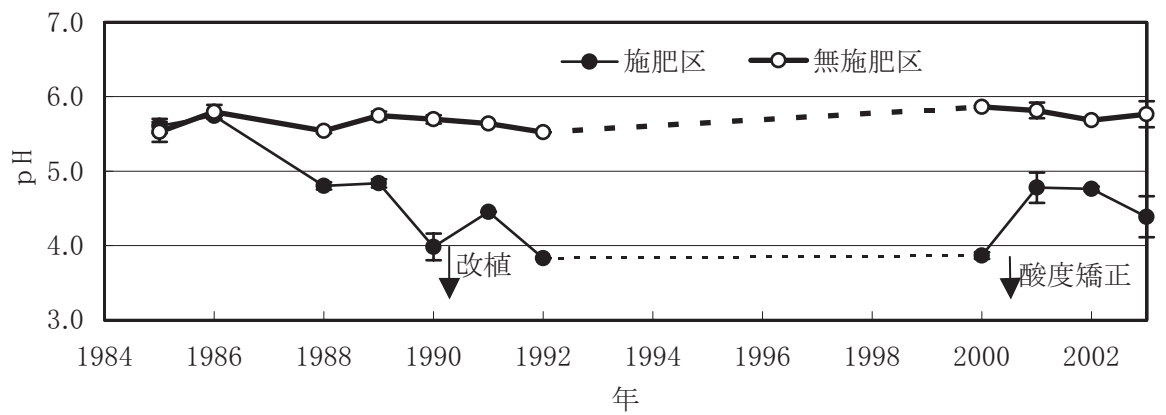

第 2 図＼cjkstart施肥および無施肥栽培区における土壌phの年次変化.

地表から $0 \sim 10 \mathrm{~cm}$ の土袞を晚秋虫期終了後（9月末～10月初）に各処理区内 3 力所 から採取した。図中のバーは処理区内の場所による測定值の変異の標準偏差を 示す．1990年に改植し，2000年晚秋虫期後に施肥区のみ酸度矯正した。
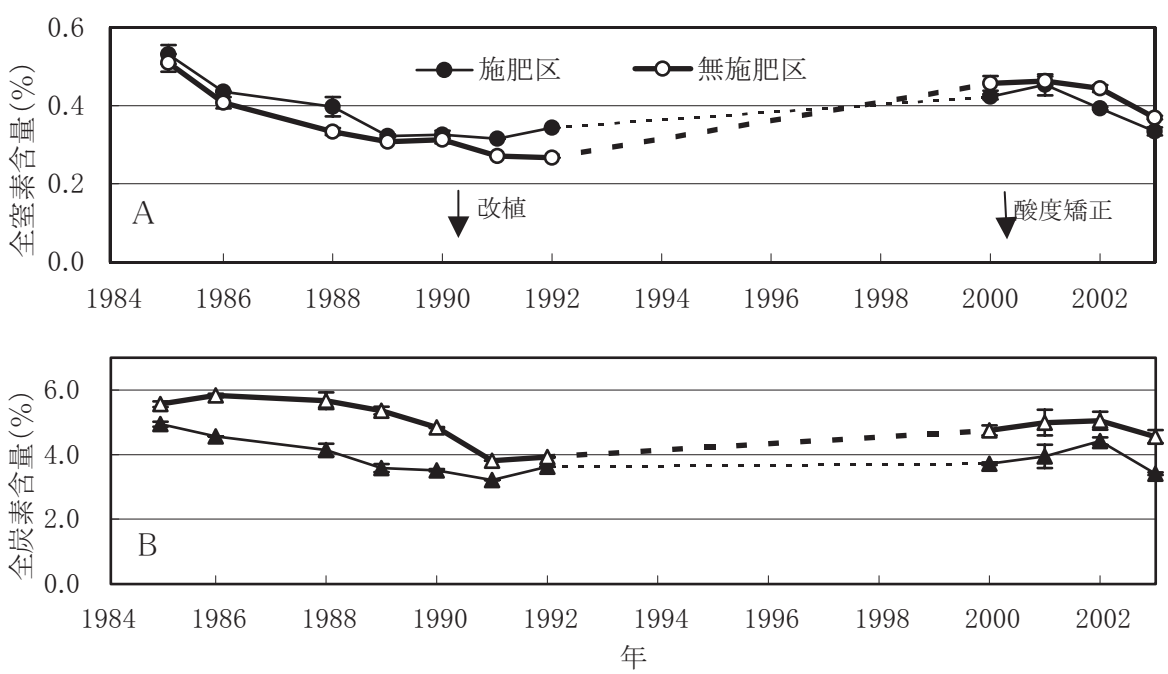

第 3 図 施肥および無施肥栽培の土壌全窒素および全炭素量の経年変化.

地表から0〜 $10 \mathrm{~cm}$ の土壤を晚秋虫期終了後（9月末～10月初）に各処理区内 3 力所 から採取した．図中のバーは処理区内の場所による測定值の変異の標準偏差を示 す．1990年に改植し，2000年晚秋虫期後に施肥区のみ酸度矯正した. 

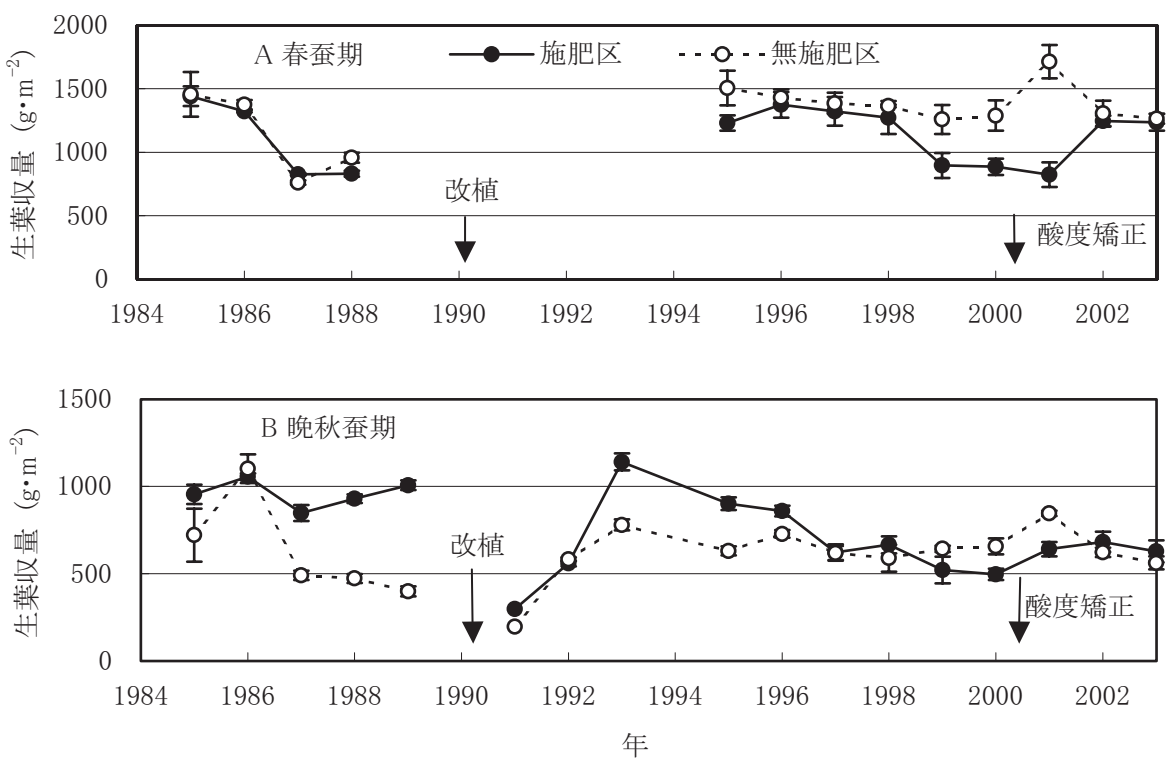

第 4 図 蟇期別収葉量の推移.

春・晚秋虫期のそれぞれ 5 令盛食期に，各区の平均的な 3 株を選び，収葉量を 測定した，実線・黒塗は施肥区を，破線・白塗は無施肥区をあらわす，図中の バーは処理区内の 3 株についての標準偏差を示寸１990年に改植し，2000年晚 秋虫期後に施肥区のみ酸度矯正した。

\section{2. 桑生葉収量とその構成要素の推移}

\section{1 改植前の期間（1985 1989 年）}

品種「改良鼠返」の株が植えられていた改植前の期間に おいては，第 4 図に示したように，施肥区で春虫期収量は 化学肥料連用 3 年目（1987 年）と 4 年目（1988 年）に処 理開始時の約 $60 \%$ に低下したが，晚秋虫期の生葉収量は この間ほぼ一定の值を保っていた。無施肥区では試験開始 3 年目（1987 年）以降に春・晚秋両虫期とも，収量が 1〜 2 年目のそれの約 $60 \%$ に減少した。そのため春虫期には施 肥・無施肥の処理区間には収量の差異は認められなかった が，晚秋虫期には，1987 年以降，無施肥区が施肥区の 40 ～58\%となり，両区の間には $\mathrm{p}<0.01$ で有意な差異が認め られた。

\section{2 改植後の期間（1991 2002 年）}

改植後の施肥区の桑生葉収量を虫期別にみると，春虫期 では 1995〜1998 年に 1230 1370 $\mathrm{g} \mathrm{m}^{-2}$ であったものが, 1999〜2000 年には 895〜 $885 \mathrm{~g} \mathrm{~m}^{-2}$ と $33 \%$ も激減した。こ の減収は，土壌の過剩な酸性化（pH 3.85）が原因と考元 られたので, 2000 年晚秋虫期終了後に酸度矯正を行った。 酸度矯正直後の 2001 年の春蟇期の収量にはその効果がみ られなかったが，2002 年の春虫期に収量は $1245 \mathrm{~g} \mathrm{~m}^{-2}$ と なり 1998 年以前の水準まで回復し，2003 年もその量を維 持した。晚秋虫期には，改植後 3 年間は桑は順調に生育し 1993 年に $1120 \mathrm{~g} \mathrm{~m}^{-2}$ の収量をあげた後, 年次とともに減 収し，1999 2000 年には $508 \mathrm{~g} \mathrm{~m}^{-2}$ まで低下した。酸度矯 正後，2001 2003 年の晚秋虫期の桑生葉収量は 1997 1998 年の水準 $\left(643 \pm 16 \mathrm{~g} \mathrm{~m}^{-2}\right)$ まで回復した。
無施肥区の生葉収量をみると，春虫期では 1995～2003 年まで収量はおおむね 1250 ～ $1500 \mathrm{~g} \mathrm{~m}^{-2}$ の間を推移した が，2001 年のみ $1710 \mathrm{~g} \mathrm{~m}^{-2}$ の収量があった。晚秋虫期で は改植後 3 年目の収量が $780 \mathrm{~g} \mathrm{~m}^{-2}$ となり, それ以後 2003 年まで $560 \sim 730 \mathrm{~g} \mathrm{~m}^{-2}$ の収量で推移したが，2001 年のみ $850 \mathrm{~g} \mathrm{~m}^{-2}$ の収量があった。

施肥・無施肥の処理区間の差異をみると，1999～2001 年 を除くと，春虫期では無施肥区が $8 \%$ 多収となり，晚秋蟇 期では施肥区が $16 \%$ 多収となっていた。施肥区で土畩酸 性化の影響がみられた 1999〜2001 年は無施肥区が施肥区 よりも春虫期で $65 \%$ ，晚秋虫期で $29 \%$ 多収となり，それ ぞれ $\mathrm{p}<0.01$ で有意な差異が認められた。

\section{3 収量の構成要素}

桑生葉収量を, 条長と条長当の生葉重との 2 つの収量構 成要素に分けて，それらに及ぼす施肥の有無の影響を処理 開始後の年代別に第 1 表に示した。年代は春虫期では 1985 ～1988 年 (改植前)，1995１998 年（樹勢旺盛期），1999 ～2001 年（土袞酸性期），2002 2003 年（酸度矯正後）の 4 区に，晚秋虫期では 1985 1989 年（改植前），1991～ 1993 年（樹型形成期），1995 1998 年（樹勢旺盛期）, 1999 2001 年 (土畩酸性期)，2002 2003 年 (酸度矯正後) の 5 区に区分し，それぞれの年代の平均值を示した。条長 は，菅沢（1968）が春虫期では総条長が，晚秋虫期では平 均条長が収量により大きく影響を及ぼすとしていることを 考慮し，総条長と平均条長の両方を示した。

春虫期の総条長は，各年代を通じて無施肥区が施肥区よ り幾分高めに推移した。春虫期の単位条長当りの葉重には, 
第 2 表 長期にわたる化学肥料連用桑園と無施肥桑園における虫期別の葉位別の元素含有率.

\begin{tabular}{|c|c|c|c|c|c|c|c|c|c|c|c|c|}
\hline \multirow[b]{2}{*}{ 試験期 } & \multirow[b]{2}{*}{ 虫期 } & \multirow[b]{2}{*}{ 部位 } & \multicolumn{2}{|c|}{ N (\%) } & \multicolumn{2}{|c|}{$\mathrm{P} \quad(\%)$} & \multicolumn{2}{|c|}{ K (\%) } & \multicolumn{2}{|c|}{$\mathrm{C}$ a $(\%)$} & \multicolumn{2}{|c|}{ Mg (\%) } \\
\hline & & & 施肥区 & $\begin{array}{l}\text { 無施肥区 } \\
\end{array}$ & 施肥区 & 無施肥区 & 施肥区 & 無施肥区 & 施肥区 & 無施肥区 & $\begin{array}{l}\text { 施肥区 } \\
\end{array}$ & 無施肥区 \\
\hline \multirow{4}{*}{ 改植前 } & 奉 & 上位葉 & 3.22 & $\overline{3.20}$ & 2.26 & 2.26 & 0.77 & $\overline{0.99} *$ & 0.33 & $\overline{0.31}$ & 0.19 & $\overline{0.22}$ ** \\
\hline & 㚛 & 中位葉 & 3.14 & 3. 13 & 2. 07 & 1. $81 * *$ & 0.43 & $0.55 *$ & 0.61 & 0.48 ** & 0.28 & 0.27 \\
\hline & 换秋 & 上位葉 & 3. 52 & 3. 39 & 2. 19 & 2.13 & 0.72 & 0.76 & 0.48 & 0.54 & 0.20 & $0.25 * *$ \\
\hline & 㫛秋 & 中位葉 & 3. 26 & 3. 01 & 1. 71 & 1.69 & 0.45 & $0.59 * *$ & 0.85 & 0.80 & 0.28 & 0.30 \\
\hline \multirow{4}{*}{ 改植後 } & 奉 & 上位葉 & 3.07 & $\overline{3.60} *$ & 1.63 & $\overline{2.04}$ & 0.82 & 1.03 & 0.26 & 0.36 & 0.13 & $\overline{0.19} *$ \\
\hline & 㚛 & 中位葉 & 2. 64 & 2. 71 & 1.65 & 1.80 & 0.44 & $0.60 * *$ & 0.43 & 0.66 & 0.16 & $0.28 * *$ \\
\hline & 换秋 & 上位葉 & 3. 18 & 3. 03 & 1.89 & 1. 92 & 0.92 & 1. 02 & 0.34 & 0.47 & 0.13 & $0.18 *$ \\
\hline & 兟忦 & 中位葉 & 2. 69 & 2. $47 *$ & 1. 47 & 1. 33 & 0.52 & 0.50 & 0.62 & 0.64 & 0.16 & 0.18 \\
\hline
\end{tabular}

* および ** は， t 一検定で処理区間にそれぞれ $\mathrm{p}<0.05$ および $\mathrm{p}<0.01$ で有意な差が認められたことを示す. 改植前は $1985 \sim 89$ 年の，改植後は2000～03年の，それぞれの虫期の収穫期における上位葉および中位葉の元素含有率について，それぞれの期間内の計 測值をこみにして期間平均值を示した.

に示した，施肥の有無にかかわらず $\mathrm{N} ， \mathrm{P}$ およ゙ $\mathrm{K}$ の含有 率は上位葉で, $\mathrm{Ca}$ と $\mathrm{Mg}$ のそれは中位葉で高いことが認め られた。 上位葉と中位葉中の $\mathrm{N}, \mathrm{P}$ および $\mathrm{K}$ の含有率の差 は，無施肥区が施肥区よりも大きい傾向にあった。また $\mathrm{N}$, $\mathrm{P}$ および $\mathrm{K}$ の含有率は春虫期には無施肥区が大きく, 晚秋 虫期には施肥区が大きかったが， $\mathrm{Ca}$ と $\mathrm{Mg}$ は抒拧むね無施 肥区が高かった。

\section{5. 窒素収奪量の年次変化}

桑葉の収穫と枝条の伐採に伴う年間の窒素収奪量は, 改 植前（1985～1990 年）の株では，年次間で増減はあるもの の施肥区，無施肥区ともに年次とともに減少する傾向がみ られた (第 6 図)，その処理区間差をみると，無施肥区の 年間窒素収奪量は施肥区の $78 \%$ でった。

改植後（1991～2002 年）の年間窒素収奪量は，施肥区で は改植 5 年目（1995 年）まで漸次増加した後, 1998 年ま でその值を維持したが，土䁃の酸性化が著しかった 1999 2001 年には $1995 \sim 1998$ 年の $60 \%$ に減少し, 酸度矯正を行 なった後の 2002 年には打打む 1998 年の窒素収奪量に 戻った。無施肥区の窒素収奪量は 1995 年まで漸次増加し た後，2003 年までおおむねその水準を維持した。

改植後の施肥・無施肥区間での窒素収奪量の差異をみる と，1999２001 年に無施肥区が施肥区を 30～50\%上回っ
たほかは両区間に大きな差異は認められなかった。これを 虫期・部位別にみると，1999２001 年を除くと，春虫期の 葉身部は無施肥区が施肥区よりも $27 \%$ 高く, 条梢部は逆 に施肥区の方が $39 \%$ 高く,両区の間にはそれぞれ $\mathrm{p}<0.01$ で有意な差が認められた。晚秋虫期の葉身部の窒素収奪量 は施肥区が無施肥区よりも平均 19\%高い值を示したが，こ の差異は有意ではなかった。

\section{考察}

\section{1. 土壤成分の年次変化}

晚秋虫期に測定した地表から $0 \sim 10 \mathrm{~cm}$ の土壤全窒素含 量は, 施肥区, 無施肥区とも処理開始後 10 年間は減少し たものの, その後増加し, 結果的に 19 年間でほとんぞ変 化していなかった。これより，施肥，無施肥区それぞれの 窒素収支は打掠む称平衡を示しているものと考元られる。 施肥区の場合, 年間で $30 \mathrm{~g} \mathrm{~m}^{-2}$ の窒素を施肥し, 桑樹が年 間 $17.6 \pm 0.5 \mathrm{~g} \mathrm{~m}^{-2}$ （1995１998 年の平均）の窒素を収 奪しているが, これは南澤（1984）が肥料成分吸収率を窒 素で $58 \%$ としていることとほぼ合致している。しかし，無 施肥区でも年間で $17.1 \pm 0.5 \mathrm{~g} \mathrm{~m}^{-2}$ の窒素を収奪してお り, 春刈桑葉・条梢と秋葉を合計した収穫部に含まれる窒 素量に対する根株肥大生長に含まれる窒素の比率が 10 か ら 11\%である（南澤，1984）ことを考慮すると，無施肥区

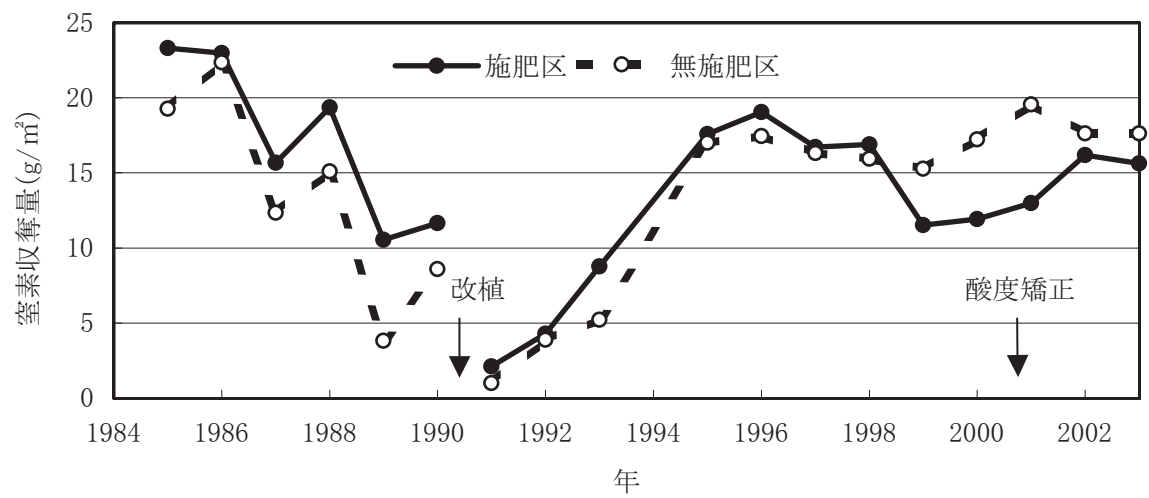

第 6 図＼cjkstart施肥および無施肥栽培の桑の年間窒素収奪量の経年変化.

春虫期の古条，新梢，全葉ならびに晚秋虫期の全葉に含まれる窒素量を合算した. 1990年に改植し，2000年晚秋虫期後に施肥区の夕酸度矯正した。1989～1993年ま では春切したため, 晚秋蚌期のみの収量を図示した。 その他は夏切した. 
の場合，年間でおよそ $19 \mathrm{~g} \mathrm{~m}^{-2}$ の窒素を土畩から吸収して いるものと推定される.

本実験の圃場では, 収穫した桑葉や条のほか, 落葉や雑 草など，すべての植物残渣が圃場外へ持ち出されており， 桑樹への窒素供給源としては, 雨水中の窒素および大気窒 素の固定, 下層土からの移動や圃場周囲からの流入および 土中において脱落した根などを利用した微生物の代謝産物 が考えられる，南澤（1984）は，桑園の標準的な天然供給 窒素量は $7.13 \mathrm{~g} \mathrm{~m}^{-2}$ year $^{-1}$ あるとしている. $\mathrm{N}$ の天然供 給のうち降水中の窒素量として, 森田・井狩 (1999) が静 岡県牧之原で 1994 1995 年に測定した值と, 田辺（1995） が香川県仲南町で 1985 年に測定した值をもとに，松本の 平均年間降水量と，本圃場で測定した降雨の流去率を用い て雨水由来の流入全窒素量を計算すると, 無施肥区では $1.34 \mathrm{~g} \mathrm{~m}^{-2}$ year $^{-1}$ となる. 土畩に浸透した雨水が全て土中 にとどまると仮定し, 窒素の土中からの溶脱, 脱窒, 揮散 などを無視しても, 無施肥区では $17.5 \mathrm{~g} \mathrm{~m}^{-2}$ 以上の窒素 が毎年供給されないと, 収支は平衡に達しないことになる。

ところで三枝 (1989), 喜田村ら (1986), 斎藤（1990） などは，畑作物の養分供給の場としての下層土に注目して いるが，これらは主に降雨などにより溶脱した施肥成分の 吸収の場としての下層土の㗢きを論じたものであった。ま た，Lilienfein and Wilcke（2003）はブラジルのサバンナに おいて深根性の植物が下層土から上層へ窒素やリンなどの 養分を移動させる可能性を示唆している．もし本戋場の 1 $\mathrm{m}$ までの土層を養分の供給元と考元かつ各土層で土壤全窒 素量（\%）の変動係数が5\%以下であったことからそれら が一様であると仮定すると，表層から $1 \mathrm{~m}$ までの土層の全 窒素含量は，2002～2003 年の平均値から算出すると施肥区 で $1684 \mathrm{~g} \mathrm{~m}^{-2}$, 無施肥区で $2061 \mathrm{~g} \mathrm{~m}^{-2}$ となり，無施肥区で 年間に収奪される窒素量はその $0.8 \%$ となる。南澤 (1984) が桑根の最も深層まで伸びているものは $4 \mathrm{~m}$ 近くに及ぶも のがあるとしている一方で，小澤・田村（1940）は，直径 $1 \mathrm{~mm}$ 以下の繊根のうち $0 \sim 30 \mathrm{~cm}$ までの土層にあるものは 無肥料区で $72 \%$ ，無機質肥料区で $79 \%$ であたとしてい るょうに，桑樹は一般に $0 \sim 30 \mathrm{~cm}$ の層で養分を吸収する とされている，地表から $30 \mathrm{~cm}$ までの全窒素含量は，施肥 区で $556 \mathrm{~g} \mathrm{~m}^{-2}$, 無施肥区で $722 \mathrm{~g} \mathrm{~m}^{-2}$ と推定され, 仮に桑 樹が吸収した窒素が全て $30 \mathrm{~cm}$ までの土層から供給された とすると，無施肥区は土壤の $2.6 \%$ の窒素を 1 年間で利 用したことになる。それらを考え合わせると，利用可能な 窒素が上層土だけでは乏しい無施肥区では, 桑根が $30 \mathrm{~cm}$ よりも下の土層からも多くの養分を吸収し，なおかつその 養分の幾分かを上層土へ放出している可能性も否定できな い.

なおニセアカシアのリターフォールによる窒素養分の還 元に伴う土壤への窒素集積量が表層から $50 \mathrm{~cm}$ の層で $67.8 \mathrm{~kg} \mathrm{ha}^{-1}$ year $^{-1}$ になるとの報告（河田，1987）もあり， 圃場に隣接する上部傾斜地に自生するニセアカシア林から
窒素が本戋場へ流入している可能性も考えられた。しかし ながら, 2003 年に $0 \sim 10 \mathrm{~cm}$ の土壤についてニセアカシア 林内，二セアカシア林と圑場を隔てる土手および圃場内の 合計 50 地点について土畩窒素含量を調査した結果（未発 表）では，表層土壃に関する限り窒素養分の流入はほとん ぞ認められなかった。下層土壇への窒素流入については現 在調査中であり, その可能性は否定できない.

一方で土壤の全炭素含量は，施肥区では試験開始当初か ら 1989 年にかけて，また無施肥区では 1989 年から 1991 年にかけて減少した。この炭素含量の減少は, 本試験開始 以前に大量に施用されていた有機物の分解によるものと推 察された，化学肥料施用区が無施肥区よりも全炭素含量の 減少が早く現れたことは, 試験開始までに蓄積された有機 物が化学肥料の施用によって分解が促進されたためと考え られる。このことは稲松ら（1991）が化学肥料のみを連用 した土壤の方が化学肥料と有機物を併用した土壤よりも腐 植の減少が早く進むとしていることと合致する，施肥・無 施肥の両区とも有機物を施用しなくなってから，6〜10 年 目には土壤炭素量の減少が止まった。このことは火山灰土 壤桑園では厩肥の有機炭素は打よそ 2.5 年で分解により $\mathrm{CO}_{2}$ として失われ, 桑条, エンバク, 稲わらなどの粗大有 機物でも 3 年程度でその大部分が失われるという報告（三 尾，1985）に従えば，試験開始までに施用された易分解性 の有機物が分解された結果と解せられる。1991〜1992 年に 施肥・無施肥の処理区間に土壤全炭素含量の差異が小さく なったことは，Jenkinson and Rayner（1977）が，20 年以上 有機物を施用した固場は, 100 年以上経過しても, 有機物 無施用の圃場よりも, 有機態炭素および窒素の含量は高い こと, および有機物施用の後, 無施肥と化学肥料のみ施用 した区間では残存有機物の量に差がないとしていることと 合致している.これらのことから, 本圃場へ試験開始まで に施用された有機物の分解におよぼす施肥の有無の影響は 1991 年ごろでなくなったものと考えられる.

本圃場では, 両処理区とも有機物の施用は行っていない が, 施肥区の全炭素含量は試験開始 6 年目以降は平衡を保 ち，無施肥区のそれは試験開始 15 年目以降には施肥区よ りも高いレベルで平衡に達した。一方で稲松・渋谷 (1991) は $60 \mathrm{~cm}$ の深さの砂耕培地で桑樹から脱落した根が炭素量 で $47 \mathrm{~g} \mathrm{~m}^{-2} \mathrm{year}^{-1}$ 蓄積したことを報じている。にもかかわ らず，本試験の施肥区・無施肥区とも土壤全炭素含量は平 衡状態を保っていたことから, Leigh (2002) が示した ように, 桑樹から脱落した繊根がある種の土壤微生物への 養分供給源になることが考えられた。これら微生物活動が 窒素の天然供給にかかわっている可能性も考えられる。こ のような微生物による非共生的な窒素固定は降雨による窒 素付加などと比べて格段に大きいとする報告 (Bormann ら , 1993）があるものの, 自然生態系における窒素収支には未 解明な点が多く, 今後の課題として残されている. 


\section{2. 収量の年次変化}

改植前の古株の生葉収量をみると，施肥区では春虫期の 収量は年次とともに大きく減少したが，晚秋虫期のそれに は大きな変化はみられなかったのに対して，無施肥区では 春・晚秋両虫期とも収量の大きな低下が認められた。この 春掻期の収量低下は，35 年以上栽培してきた桑の樹勢の 衰えと, 施肥区ではこれに加えて土壤 $\mathrm{pH}$ の低下が影響し たものと思われる。化学肥料連用 4 年目には土壤 $\mathrm{pH}$ が低 下するものの，その影響は成木の収量には顕著に現れない との報告（稲松ら，1991）があるが，本試験の施肥区の春 虫期生葉収量の年次による著しい低下は，無施肥区でも同 様な傾向が認められたことから，桑樹が老化したことで, 土壤 $\mathrm{pH}$ の変化に耐えられなかったとも考元られる。さら に稲松ら（1991）は有機物の施用が石灰無施用の化学肥料 連用区の収量低下を抑えるとしているが，本実験では試験 開始から 7 年目までの期間に施肥区の全炭素含有率の低下 が認められたことから，試験開始までの施用有機物の効果 が徐々になくなってきたことも収量低下にかかわっている と推察された。

施肥区の収量の年次低下が春虫期のみにみられ，晚秋蟇 期にみられなかった理由として，次のことが考えられる. すなわち桑の春虫期の初期生育には前年秋期から蓄積され た養分が影響し（山本，1979），当年の施肥効果が顕著に 現れるのは，春虫期の中期から晚秋蟇期の後期までである （野木，1996）ことから，樹体が老化した 1987 年以降の施 肥区では根の活力が劣り, 施肥直後の豊富な養分は吸収利 用できるものの，秋から翌春にかけて無機化する土壤養分 を吸収蓄積する能力が衰えてきたのではないかと推察され た。 また無施肥区の収量低下が処理開始後 4 年目の 1987 年からみられたことは，太田ら（1961）が無施肥後 3〜4 年目の桑葉に養分欠乏症状が発現したと報じていることと 合致した。

改植後の施肥区の収量の推移は, 植付後の桑の生育最盛 期は $5 \sim 8$ 年（南澤, 1984） あるいは最大収量期は $3 \sim 6$ 年 （稲松ら，1991）であり，その後樹勢が衰え収量が低下す るというこれまでの報告と拧抒む致したパターンを示 した。改植後 9 11 年目に施肥区の春虫期の収量が大幅に 減収したのは，樹勢の衰えに加えて，施肥区の土畩 $\mathrm{pH} の$ 低下による養分吸収能力の低下が大きく影響していると考 えられる。土畩酸性化が桑樹の発育におよぼす影響は，加 藤・三輪（1938）や小山・福田（1938）など古くから数多 くの報告があり, 南澤（1984）は土畩酸性化は, 石灰とマ グネシウムの欠乏や有用土畩微生物の活性低下などをもた らし，地上部，根部ともに著しい生育低下を招くことを示 している。このことは施肥区の葉身中の $\mathrm{Ca}$ 抢よび $\mathrm{Mg}$ 含 有率 (第 2 表) が無施肥区のそれよりも低かったことや, 1999 年から施肥区の乾物生産量（第 5 図）が条梢部，葉身 部ともに大きく減少していることでも確かめられた。 2000 年の晚秋虫期後に行なった酸度矯正の効果は，直後の 2001
年春虫期の収量にはみられず， 2001 年の晚秋虫期の収量か ら認められるょうになった。

ところで, 改植後の無施肥区の収量動態はこれまでの報 告にはほとんどみられないものであった。これまでの報告 では，たとえば小澤・田村（1940）は，本戋場と土壌は異 なるが，荒川沖積細壤土において無施肥区の収量は化学肥 料施用区に比べて植付後 3 年目で $78 \%, 10$ 年目で $48 \%$, 13 年目で $35 \%$ になるとしている。しかしながら, 本試験 では植付け 5 年目以降の 9 年間の無施肥区の平均収量は $2027 \pm 82 \mathrm{~g} \mathrm{~m}^{-2}$ であり，伊東・森（1966）が腐植質火山 灰土壤での桑園生産力を $1535 \pm 565 \mathrm{~g} \mathrm{~m}^{-2}$ としていること からも，本実験の無施肥区の土畩生産力が劣っているとは 言いがたかった。ささらに, これまでの報告にある無施肥裁 培での収量の大幅な減少や養分欠乏症状は認められなかっ た.

無施肥区でこのように高い収量を可能にしている一因と して，施肥区と無施肥区で養分の吸収パターンと，その各 器官への分配率が異なることが考えられる。一般に桑樹の 1 年の生育過程は, 前年からの貯蔵養分を消費して生長す る展開期と，展開葉が生産した同化産物によって生長する 同化期，生長が衰えつつある秋に枝条や根に養分を貯蔵す る貯蔵期, 初冬の休眠期, 冬から春の萌芽までの冬眠期に 分けることができる（南澤，1984）。今西・五島（1981） が指摘するように，気象条件によって展開期と同化期の境 は 4 月下旬から 5 月中旬まで幅があると考光られるが，い ずれにしても, 前述のように, 前年秋期から蓄積された養 分が春虫期の桑の初期生育に大きな影響を与える（山本, 1979）ことから, 当年の施肥効果が顕著に現れるのは, 春 虫期の中期以降（野木，1996）とみなすことができる.

本実験で土畩酸性化の影響があらわれていない 1995〜 1998 年には施肥・無施肥の両処理区とも春虫期の収量は晚 秋虫期のそれの約 2 倍であった。これは供試桑樹は夏切処 理をしているために, 春から秋にかけては葉の生育だけで なく条の生育にも無機養分や同化産物が使われており, 春 虫期の方が葉の生産に利用される養分や同化産物の割合い が高いことを反映していると考えられる。また春虫期と晚 秋虫期との収量の差は，無施肥区の方が施肥区ょりも大き かった。施肥区では春から秋にかけて当年に施肥された養 分を展開期から同化期の短期間に利用できることが，春と 秋の収量差を小さくしていると推察された。一方, 無施肥 区では秋から初冬の同化期から貯蔵期にかけて長期間にわ たって土壤から無機化する養分の吸収・蓄積に依存する春 虫期の桑葉収量は高く維持していたが，展開期から同化期 にかけての短期間の養分吸収に依存する晚秋虫期の桑葉収 量は低くなった。さらに, 無施肥区では乾物生産の桑葉へ の分配が高いのに対し, 施肥区では条梢部への分配が高い ことも，無施肥区の多収の要因となっていた。このように 無施肥裁培の長期継続によって養分の吸収パターンや乾物 の分配に違いが生じることが示唆された。 
いずれにしても無施肥裁培でこのように高い桑葉収量が 得られるにはそれに見合う窒素の供給が不可欠である。先 に示したように本実験の圃場では年間 $17.5 \mathrm{~g} \mathrm{~m}^{-2} も$ の窒 素が供給されていると見積もられた。この窒素源として, 下層土からの養分移動, 圃場周囲からの養分流入や土壤微 生物による窒素固定などが考えられたが，その詳細につい ては今後の研究課題としたい.

\section{引用文献}

Bormann, B.T., F.H. Bormann, W.B. Bowden, R.S. Piece, S.P. Hamburg, D. Wang, M.C. Snyder, C.Y. Li and R.C. Ingersoll 1993. Rapid N2 Fixation in Pines, Alder, and Locust: Evidence From the Sandbox Ecosystems Study. Ecology 74 : 583-598.

土壌環境分析法編集委員会編 1997. 土壌環境分析法. 博友社, 東京. $195-233$.

長谷川浩 - 竹内史郎 - 奥村俊勝 - 江菅洋一 1977. 長期無施肥田にお ける水稲諸形質の位置的変動. 近畿作育談話会報 $22: 1-4$.

今西三好・五島晧 1981. 山陰地方に打ける桑樹の春の発育と養分の 吸収利用について 第 2 報 $15 \mathrm{~N}$ による春肥窒素の吸収開始時期と 分配の検討.蟇糸研究 $118: 29-33$.

稲松勝子 - 渋谷加代子 1991. クワ裁培に伴う砂耕培地中の有機物蓄 積.土肥誌 $62: 345-356$.

稲松勝子・鈴木誠 - 木内美江子 - 渋谷加代子 1991. 所内桑園（125 号, 205 号) における土袞と桑収量の調査.虫昆研資料 $8: 1-21$.

伊東正夫 · 森信行 1966. 本邦桑園の土壤類型と施肥改善に関する調 查研究. 昙試報告 $21: 1-371$.

Jenkinson, D.S. and J.H. Rayner 1977. The turnover of soil organic matter in some of the Rothamsted classical experiments. Soil Science $123: 298-305$.

上村親士 - 古賀進 - 橋本昭彦 - 松石直樹 - 鳥浜義巳 - 西口達郎 - 篠 原公人 1997. 桑園生産力に及ぼす諸因子の影響. 日虫雑 $66: 176-$ 191.

加藤清時・三輪貞徳 1938. 土袞酸度が桑葉葉質並桑樹発育に及ぼす 影響.土肥誌 $13: 591-596$.

河田弘 1987. 海岸砂丘地におけるクロマツ林とニセアカシア林のリ ターフォールによる土㙵への養分還元量の相違とそれが土壌の諸 性質に及ぼす影響. 新大演報 $20: 51-66$.

川村三郎・中島照夫 1979. 長期無施肥水田土㙥における二三の植物 養分の動態について. 近畿大学農学部紀要 $12: 157-169$.

喜田村俊明・庄子貞雄・尾形佳彦・竹田康夫・秋谷達司 1986. バー レー種タバコに対する黒ボク土下層からの無機態窒素の供給につ いて.土肥誌 $57: 414-417$.

小山総夫 - 福田徳司 1938. 桑園酸性土袞に関する研究（第一報）酸 性土壌が桑葉の養分吸収に及ぼす影響.土肥誌 $13: 852-860$.

葉田光雄・堀江武 2002. 異なる施肥量で裁培した桑葉の虫児誘引性 におよぼす影響.日虫雑 $71: 75-81$.
葉田光雄・堀江武 2004. 異なる施肥量で裁培した桑葉がカイコのフ ロキシンに対する感受性におよぼす影響. 日虫雑 $73: 71-76$.

Leigh, M.B., J.S. Fletcher, X. Fu and F.J. Schmitz 2002. Root turnover: an important source of microbial substrates in rhizosphere remediation of recalcitrant contaminants. Environ. Sci. Technol. 36 : $1579-1583$.

Lilienfein, J. and W. Wilcke 2003. Element storage in native, agri-, and silvicultural ecosystems of the Brazilian savanna. Plant and Soil 254 : 425-442.

南澤吉三郎 1984. 栽桑学一基礎と応用一（改訂新版）. 鳴鳳社出版, 東京. 80-348.

三尾智秋 1985. 火山灰土桑園に打ける有機物消耗量に関する研究. 虫試報告 $29: 703-730$.

水野直治 - 南松雄 1980. 硫酸一過酸化水素による農作物中 $\mathrm{N}, \mathrm{K}, \mathrm{Mg}$, $\mathrm{Ca}, \mathrm{Fe}, \mathrm{Mn}$ 定量のための迅速前処理法. 土肥誌 $51: 418-420$.

森田明雄 - 井狩寅三郎 1999. 静岡県牧之原地域における降雨の酸性 度と養分供給量. 静岡茶試研報 $22: 1-8$.

野木照修 1996. 寒冷地桑園における施肥栽培法と施肥窒素の土袞中 での挙動, 並びに桑樹による吸収利用. 福島虫試研報 29:1-84.

太田安澄・井出智 - 岡田和人 1961. 窒素 - 燐酸 - 加里施用の有無と 桑の収量及び育虫成績について.虫糸界報 $70: 16-20$.

奥村俊勝 1988. 水稲の窒素栄養の動態からみた無施肥田と施肥田の 比較栽培学的研究. 京都大学博士論文 (国立国会図書館, 博士論文 目録 $89-\mathrm{A}-86$ ).

奥村俊勝 - 竹内史郎 1999. 長期無施肥田における水稲諸形質の位置 的変動（その 3). 近畿作育研究 $44: 27-30$.

Okumura, T. 2002. Rice production in unfertilized paddy field -Mechanism of grain production as estimated from nitrogen economy-. Plant Prod. Sci. 5 : 83-88.

小澤昇・田村義憲 1940. 有機質並に無機質肥料の連用が桑樹の収量, 根系及び土㙵に及ぼす影響（第一報）.土肥誌 $14: 723-734$.

小澤昇・田村義憲 1941. 有機質並に無機質肥料の連用が桑樹の収量, 根系及び土壤に及ぼす影響（第二報）.土肥誌 $15: 107-118$.

三枝正彦 1989. 下層土と作物の生育一下層土のエダホロジー一。化 学と生物 $27: 712-720$.

斎藤雅典 1990. 黒ボク土畑戒場における土壤有機態窒素の無機化と その移動一デル化によるシミュレーションとその検証一東北農試 研報 $82: 63-76$.

菅沢春吉 1968. 桑の収量予測方法に関する研究. 虫試報告 $22: 329-$ 349.

高岸秀次郎・白田和人 ・ 川内郁緒 1985. 肥培による土壌肥沃度の推 移と桑の施肥感応に関する調査研究. 虫試報告 $30: 19-63$.

田辺和司 1995. 林地の降雨に伴う全窒素及び全りんの動態. 香川農 試研報告 $46: 73-76$.

山田政枝・何克栄・稲松勝子 1992. 肥培管理の相違が桑葉タンパク 質構成アミノ酸組成に及ぼす影響. 日虫杂隹 $61: 469-479$.

山本有彦 1979. 桑の栄養生理. 福田紀文監修, 総合虫糸学. 日本虫糸 新聞社, 東京. 95-99. 
Changes in Total Nitrogen and Total Carbon Contents in Soil and the Leaf Yield of a Long-Term Unfertilized Mulberry under Field Condition : Mitsuo Kuwada, Tatsuhiko Shiraiwa and Takeshi Horie (Department of Crop Science, Graduate School of Agriculture, Kyoto University, Kyoto 606-8502, Japan)

Abstract : Total nitrogen and total carbon contents of the soil and the leaf yield in a long-term unfertilized mulberry field (NF) were compared with those in a chemically fertilized field (F) for 19 years from 1985 to 2003 . Each year, 30,20 and $20 \mathrm{~g} \mathrm{~m}{ }^{-2}$ of nitrogen, phosphorus and potassium, respectively, were applied to the F field; a half in spring and the remaining half in summer. Weeds and litter fall were all removed from both $\mathrm{F}$ and NF fields. Originally, the mulberry cultivar Kairyonezumigaeshi had been grown in both fields for more than 25 years. In the spring of 1991 (the 7 th year of the experiment), mulberry (cv. Ichinose) was replanted to both fields. The mulberry leaves were harvested twice a year in spring and in late-autumn, by cutting and leaf plucking methods, respectively. Total soil nitrogen and carbon contents of the soil in the NF field reached equilibrium after 15 years of treatment, and the yearly yield of fresh leaves from NF was stable at 1800 to $2000 \mathrm{~g} \mathrm{~m}^{-2}$ for 5 years after replanting. The changes in nitrogen content of the plant and that of soil nitrogen suggested $17.5 \mathrm{~g} \mathrm{~m}^{-2}$ of nitrogen was annually input to the NF field from the natural environment. The source of nitrogen input remains unknown, but a major part of nitrogen was supposed to come from the nitrogen pool in the subsoil layers, from adjacent environment and/or through atmospheric nitrogen fixation. In the spring rearing season, during which the time interval between successive harvesting was long and fertilizer application was less effective, the leaf yield was higher in the NF field than in the F field. On the other hand, in the late-autumn rearing season, during which intervals between successive harvesting was short and applied fertilizer was effective, the leaf yield was higher in the F field than in the NF field. The rate of nitrogen content allocation to leaf blades was higher in the NF than in the F field, even though the nitrogen content of the whole plant was lower in the NF field. The characteristic nutrient distribution pattern in the plant may also be a reason for the higher leaf yield in the unfertilized field.

Key words : Long-term unfertilized cultivation, Mulberry, Total soil carbon, Total soil nitrogen, Yearly leaf yield. 